\title{
Climate change and gene patents
}

\author{
Michael Blakeney \\ Professor of Law, Faculty of Law, University of Western Australia; Visiting Professor in Intellectual \\ Property and Agriculture, Queen Mary University of London, UK
}

Climate change is imposing significant stresses upon agriculture at a time when more food is required for an increasing world population. Genetic engineering is mooted as a technological response to these difficulties. The modification of the DNA of major crop groups produces plants which are more resistant to drought, salinity and to pests. The patenting of climate-useful DNA provides an opportunity to protect the investment in the exploitation of this DNA. The international IPR regime based upon the WTO TRIPS Agreement enables the patenting of this DNA across the globe. As a matter of practice, this patenting is confined to a relatively small group of life-sciences companies. This market concentration has important agricultural policy implications, particularly for developing countries. This article analyses these issues, concluding that the impact of patenting upon food security is becoming as significant as the impact of patenting upon access to medicines.

Keywords: intellectual property, agriculture, patenting, DNA, climate change

\section{INTRODUCTION}

Since the late 1980s a number of studies have predicted the significant adverse impacts of climate change upon world food supplies both generally ${ }^{1}$ and in relation to

1. Eg see B Smit, L Ludlow and M Brklacich 'Implications of a Global Climatic Warming for Agriculture: A Review and Appraisal' (1988) 17(4) Journal of Environmental Quality, 519-27; C Rosenzweig and ML Parry, 'Potential Impact of Climate Change on World Food Supply' (1994) 367 Nature 133-8; R Mendelsohn, W Nordhaus and D Shaw, 'The Impact of Global Warming on Agriculture: A Ricardian Analysis' (1994) 84(4) American Economic Review 753-71; C Rosenzweig and A Iglesias (eds), Implications of Climate Change for International Agriculture: Crop Modeling Study, EPA 230-B-94-003 (US Environmental Protection Agency, Washington DC 1994); ML Parry, C Rosenzweig, A Iglesias, G Fischer and MTJ Livermore, 'Climate Change and World Food Security: A New Assessment' (1999) 9 Global Environmental Change S51-S67; G Fischer, M Shah and H van Velthuizen, Climate Change and Agricultural Vulnerability, IIASA Special Report commissioned by the UN for the World Summit on Sustainable Development, Johannesburg 2002 (International Institute for Applied Systems Analysis, Laxenburg, Austria 2002); R Darwin, 'Effects of Greenhouse Gas Emissions on World Agriculture, Food Consumption, and Economic Welfare' (2004) 66 Climatic Change 191-238; M Parry, C Rosenzweig and M Livermore, 'Climate Change, Global Food Supply and Risk of Hunger' (2005) 360 (1463) Philosophical Transactions of the Royal Society London B: Biological Sciences 2125-38; SM Howden, JF Soussana, FN Tubiello, N Chhetri, M Dunlop and HM Meinke, 'Adapting Agriculture to Climate Change' (2007) 104 Proceedings of the National Academy of Sciences 19691-6; J Quiggin, The Impact of Climate Change on Agriculture, Australian Public Policy Program Working Paper: C08\#3, August 19 2008 . 
developing countries in particular. ${ }^{2}$ The key findings of the 2001 Third Assessment Report of the United Nation's Intergovernmental Panel on Climate Change (IPCC) ${ }^{3}$ with respect to food, fibre, forestry and fisheries were that: $\mathrm{CO}_{2}$ effect may be relatively greater (compared to that for irrigated crops) for crops under moisture stress; and crop yields would decline in both the tropics and mid to high latitudes with associated declines in plant health. The Report observed the possibility of increases in diseases and algal blooms in the aquaculture industry as seawater temperatures rise. The conclusions of the Panel's Fourth Assessment Report (2007) was that 'climate change alone is estimated to increase the number of undernourished people to between 40 million and 170 million' and 'is likely to further shift the regional focus of food insecurity to sub-Saharan Africa' such that 'by 2080 , about $75 \%$ of all people at risk of hunger are estimated to live in this region'. ${ }^{4}$ A number of studies have highlighted the influence of climate change upon the development of weeds, insect pests

2. S Gadgil, AKS Huda, NS Jodha, RP Singh and SM Virmani, 'The Effects of Climatic Variations on Agriculture in Dry Tropical Regions of India' in ML Parry, TR Carter and NT Konijn (eds), Assessments in Semi-Arid Regions (Kluwer Academic Publishers, Dordrecht 1988) 495-521; TE Downing, 'Vulnerability to Hunger and Coping with Climate Change in Africa' (1991) 1 (5) Global Environmental Change 365-80; S Kane, J Reilly and J Tobey, Climate Change: Economic Implications for World Agriculture (Resources and Technology Division, Economic Research Service, US Department of Agriculture, Agricultural Economic Report No. 647 1991); P Muchena and A Iglesias, 'Vulnerability of Maize Yields to Climate Change in Different Farming Sectors in Zimbabwe' (1995) 59 American Society of Agronomy, Special Publication, 229-39; A Iglesias, L Erda and C Rosenzweig, 'Climate Change in Asia: A Review of the Vulnerability and Adaptation of Crop Production' (1996) 92(1/2) Water, Air, and Soil Pollution 13-27; C Benson and E Clay, The Impact of Drought on Sub-Saharan African Economies. World Bank Technical Paper No. 401 (The World Bank, Washington DC 1998); AF Abou-Hadid, Assessment of Impacts, Adaptation and Vulnerability to Climate Change in North Africa: Food Production and Water Resources (Assessments of Impacts and Adaptations to Climate Change, Washington DC 2006); J Adejuwon, Food Security, Climate Variability and Climate Change in Sub Saharan West Africa (Assessments of Impacts and Adaptations to Climate Change, Washington DC 2006); PK Aggarwal, 'Impact of Climate Change on Indian Agriculture' (2003) 30 J. Plant Biol 189-98; AC Chipanshi, R Chanda and O Totolo 'Vulnerability Assessment of the Maize and Sorghum Crops to Climate Change in Botswana' (2003) 61 Climatic Change, 339-60; TA Butt, BA McCarl, J Angerer, PT Dyke and JW Stuth, 'The Economic and Food Security Implications of Climate Change in Mali' (2005) 68 Climatic Change 355-78; L Erda, X Wei, J Hui, X Yinlong, L Yue, B Liping and X Liyong, 'Climate Change Impacts on Crop Yield and Quality with CO2 Fertilization in China' (2005) 360 Philos. T. Roy. Soc. B 2149-54; C Vogel, 'Seven Fat Years and Seven Lean Years? Climate Change and Agriculture in Africa' (2005) 36 IDS Bull-I Dev. Stud. 30-35; G Xiao, W Liu, Q $\mathrm{Xu}, \mathrm{Z}$ Sun and J Wang, 'Effects of Temperature Increase and Elevated CO2 Concentration, with Supplemental Irrigation, on the Yield of Rain-fed Spring Wheat in a Semiarid Region of China' (2005) 74 Agr. Water Manage., 243-55; XC Zhang and WZ Liu, 'Simulating potential response of hydrology, soil erosion, and crop productivity to climate change in Changwu tableland region on the Loess Plateau of China' (2005) 131 Agr. Forest Meteorol. 127-42; C Müller, W Cramer, WL Hare and H Lotze-Campen, 'Climate Change Risks for African Agriculture' (2011) Proceedings of the National Academy of Sciences <http://www.pnas.org/content/early/ 2011/02/23/1015078108.full.pdf+html>.

3. Available at $<\mathrm{http}: / / \mathrm{www}$.grida.no/publications/other/ipcc_tar/>.

4. ML Parry, OF Canziani, JP Palutikof, PJ van der Linden and CE Hanson (eds), Contribution of Working Group II to the Fourth Assessment Report of the Intergovernmental Panel on Climate Change, 2007 (Cambridge and New York, Cambridge University Press 2007), para 5.8.1. 
and crop diseases ${ }^{5}$ and the ways in which plants can be engineered to withstand salinity $^{6}$ and aridity. ${ }^{7}$

These agricultural stresses arising from climate change present opportunities for innovators. IPRs have been identified as a means for incentivizing the development of $\mathrm{CO}_{2}$ and $\mathrm{N}^{2} \mathrm{O}$ abatement strategies through the management of animal feed to alter the rumen microbial population and its activity. ${ }^{8}$ Similarly, computer software decision support tools, based on biophysical models of the agronomic system, have been identified as offering considerable scope to reduce $\mathrm{N}^{2} \mathrm{O}$ emissions from broad acre agriculture and emissions from wet rice cultivation by optimizing management of agricultural inputs such as fertilizers. ${ }^{9}$ At the genomic level, climate change has led to the identification and patenting of stress-tolerant genes.

\section{INTERNATIONAL INTELLECTUAL PROPERTY INFRASTRUCTURE}

The global commercial significance of climate technologies is assured by the global reach of the international intellectual property (IP) regime. Members of the World Trade Organization (WTO), which include some 153 countries as of 23 July $2008,{ }^{10}$

5. B Boag, JW Crawford and R Neilson, 'The Effect of Potential Climatic Changes on the Geographical Distribution of the Plant-parasitic Nematodes Xiphinema and Longidorus in Europe' (1991) 37 Nematologica, 312-23; A Iglesias and C Rosenzweig, 'Climate and Pest Outbreaks' in D Pimentel (ed), Encyclopedia of Pest Management (Marcel Dekker, New York 2002); MC Todd, R Washington, RA Cheke and D Kniveton, 'Brown Locust Outbreaks and Climate Variability in Southern Africa' (2002) 39 J. Appl. Ecol. 31-42; LH Ziska and K George, 'Rising Carbon Dioxide and Invasive, Noxious Plants: Potential Threats and Consequences' (2004) 16 World Resource Review 427-47; J Agrell, P Anderson, W Oleszek, A Stochmal and C Agrell, 'Combined Effects of Elevated CO2 and Herbivore Damage on Alfalfa and Cotton' (2004) 30 J. Chem. Ecol. 2309-24; FJ Chen, G Wu and F Ge, 'Impacts of Elevated CO2 on the Population Abundance and Reproductive Activity of Aphid Sitobion Avenae Fabricius Feeding on Spring Wheat' (2004) 128 J. Environ. Nutr. 723-30; S Chakraborty and IB Pangga, 'Plant Disease and Climate Change', in M Gillings and A Holmes (eds), Plant Microbiology (BIOS Scientific, London 2004), 163-80; KA Garrett, SP Dendy, SG Pritchard and JS Amthor, Crops and Environmental Change (Binghamton, Food Products Press 2005); RN Strange and PR Scott, 'Plant Disease: A Threat to Global Food Security' (2005) 43 Annual Review of Phytopathology 83-116; EE Frank, MN Rouse and SE Travers, 'Climate Change Effects on Plant Disease: Genomes to Ecosystems' (2006) 44 Annual Review of Phytopathology 489-509; T Kobayashi, K Ishiguro, T Nakajima, HY Kim, M Okada and K Kobayashi, 'Effects of Elevated Atmospheric $\mathrm{CO} 2$ Concentration on the Infection of Rice Blast and Sheath Blight' (2006) 96 Phytopathology 425-31.

6. Eg TJ Flowers, 'Improving Crop Salt Tolerance' (2004) 55 (396) J. Exp. Bot. 307-19.

7. L Cattivelli, F Rizza, FW Badeck et al., 'Drought Tolerance Improvement in Crop Plants: An Integrated View from Breeding to Genomics' (2008) 105 Field Crops Res 1-14; R Tuberosa and S Salvi, 'Genomics-based Approaches to Improve Drought Tolerance of Crops' (2006) 11 Trends Plant Sci. 405-12.

8. R Thomson and E Webster, 'The Role of Intellectual Property Rights in Addressing Climate Change: The Case for Agriculture' (2010) 2(1) The WIPO Journal 133-141.

9. Thomson and Webster, ibid, refer to an interactive computer-based decision support tool called 'Nutrient Manager' developed by International Rice Research Institute (IRRI) which calculates the optimal amounts of fertilizer to be applied.

10. See <http://www.wto.org/english/thewto_e/whatis_e/tif_e/org6_e.htm> accessed 8 December 2011. 
are obliged to introduce IP laws which implement the norms prescribed by the WTO Agreement on Trade-Related Aspects of Intellectual Property Rights ('TRIPS Agreement'). Key provisions in the present context are Article 23.1 which provides that 'patents shall be available for any inventions, whether products or processes, in all fields of technology, provided that they are new, involve an inventive step and are capable of industrial application'. This provision requires also that 'patents shall be available and patent rights enjoyable without discrimination as to the ... field of technology'. The effect of this provision is to establish a patenting regime which extends to all WTO Members. Additionally, Article 27.3(b) of the TRIPS Agreement requires that WTO Members 'shall provide for the protection of plant varieties either by patents or by an effective sui generis system or by any combination thereof'.

Although the TRIPS Agreement does not prescribe a sui generis system for the protection of plant varieties, most countries have adopted the 1991 version of the International Convention for the Protection of New Varieties of Plants (UPOV). Thus to 15 January 2011 the UPOV Convention has 70 signatories, with 41 of those joining after 1 January $1995 .{ }^{11}$ Despite numerous commentaries and proposals for the adoption of alternative sui generis models, ${ }^{12}$ only a few countries have adopted alternatives to UPOV. One of the reasons why countries have tended to adopt UPOV 1991, rather than crafting a sui generis alternative, is that the IPR chapters in the free trade agreements ('FTAs'), signed since the 1990s by the USA and the EU with their various bilateral partners, includes the obligation to subscribe to the 1991 version of UPOV. UPOV provides for the protection of new plant varieties which are 'distinct', 'uniform' and 'stable'. Excepted from protection under the 1978 version of UPOV, was propagating material which had been harvested by farmers and retained for further planting or for sale. Article 15 (2) of the 1991 version of the UPOV Convention confined this seed saving exception to the use of saved material for propagating purposes in farmers' own holdings and in reasonable quantities. UPOV 1991 also permits the use of protected varieties for the purpose of breeding new varieties. As is indicated below, where a new variety can be patented, the seed saving and breeding exceptions become irrelevant.

\section{PATENTING OF DNA}

The modern biotechnological revolution has enabled the engineering of desirable genetic traits from useful local species. These include: (i) pest control traits such as insect, virus and nematode resistance, as well as herbicide tolerance, and post-harvest traits such as delayed ripening of spoilage prone fruits; (ii) agronomic traits such as nitrogen fixation and utilization, restricted branching, environmental stress tolerance,

11. <http://www.upov.int/members/en/> accessed 20 January 2011.

12. Eg D Leskien and M Flitner, 'Intellectual Property Rights and Plant Genetic Resources: Options for a Sui Generis system' Issues in Genetic Resources no 8 (International Plant Genetic Resource Institute, Rome 1997); Biswajit Dhar, Sui Generis Systems for Plant Variety Protection. Options under TRIPS. A Discussion Paper (Geneva, QUNO 2002); LR Helfer, Intellectual Property Rights in Plant Varieties: An Overview with Options for National Governments. FAO Legal Papers Online \#31 (FAO, Rome 2002); D Robinson, Exploring Components and Elements of Sui Generis Systems for Plant Variety Protection and Traditional Knowledge in Asia (Geneva, UNCTAD, IDRC and ICTSD 2007); D Robinson, 'Sui Generis Plant Variety Protection Systems: Liability Rules and Non-UPOV Systems of Protection' (2008) 3(10) Journal of Intellectual Property Law \& Practice 659-65. 
and male and/or seed sterility for hybrid systems; and (iii) output traits such as plant colour and vitamin enrichment. The production of transgenic plants has become possible through the development of a number of enabling and transformation technologies.

A key issue around the patenting of genetic resources was whether a DNA sequence could be characterized as an 'invention'. In the early history of patent law an invention was thought to involve some kind of technical innovation and a distinction was drawn between patentable inventions and non-patentable discoveries. The US Supreme Court in its 1980 determination, Diamond $v$ Chakrabarty, ${ }^{13}$ held in a 4:3 majority decision that a bacterium genetically engineered to degrade crude oil was an invention. This decision provided the legal underpinning for the US biotechnology industry. The European Parliament's belated response in 1998 was its Biotechnology Directive $^{14}$ which provided in Article 3.2 that biological material which is isolated from its natural environment or produced by means of a technical process is deemed to be an invention even if this material previously occurred in nature'.

The patentability of genetic materials and gene fragments, such as expressed sequence tags (ESTs) and single nucleotide polymorphisms (SNPs), as well as enabling gene-based technologies, led to what has been described as a 'genomic gold rush' in the 1990s, as vast numbers of gene-based patent applications were filed, particularly in the USA. ${ }^{15}$ Significant misgivings were expressed by numerous commentators. Probably the most influential among these were HelIer and Eisenberg who suggested that genetic research tool patents could create a 'tragedy of the anticommons' in which multiple patent owners would tie-up genetic materials in a thicket of IP patent rights. ${ }^{16}$ This was perceived to be a particular problem for the genetic improvement of crops since this is an incremental process and each new patent would constrain the 'freedom to operate' particularly of public agricultural research institutes. ${ }^{17}$

Arguably, this gold rush has been brought to an end, at least in the USA, by the In re Fisher ${ }^{18} 2005$ decision of the US Court of Appeals for the Federal Circuit which upheld a ruling by the US Board of Patent Appeals and Interferences refusing to allow patent applications made on behalf of Monsanto Co on five ESTs encoding protein and protein fragments in maize plants grown by the Asgrow Seed Company of Des Moines, Iowa. ${ }^{19}$ It is suggested that that the Fisher case was used by Monsanto Co, a significant downstream user of research tools, to urge upon the Court a higher patentability standard in order to eliminate the thousands of research tool patents

\section{447 US 303 (1980).}

14. Directive 98/44/EC of the European Parliament and of the Council of 6 July 1998 on the legal protection of biotechnological inventions, Official Journal L 213, 30/07/1998 P. 0013 0021.

15. Eg see Y Joly, 'Accès aux mèdicaments: le système international des brevets empêchera-t'il les pays du tiers monde de bénéficier des avantages de la pharmacogénomique' (2003) 16 Les cahiers de Propriété intellectuelle 135.

16. MA Heller and RS Eisenberg, 'Can Patents Deter Innovation? The Anticommons in Biomedical Research' (1998) 280 Science 698-701, 700.

17. See the authorities referred to in CM Correa, 'Trends in Intellectual Property Rights Relating to Genetic Resources for Food and Agriculture', Background Study Paper 49, Commission on Genetic Resources for Food and Agriculture, October 2009, 2.

18. 421 F.3d 1365 (Fed. Cir. 2005).

19. Eg claim no 1 of application $09 / 619,643$ reads: 'A substantially purified nucleic acid molecule that encodes a maize protein or fragment thereof comprising a nucleic acid sequence selected from the group consisting of SEQ ID NO: 1 through SEQ ID NO: 5'. 
which were cluttering research efforts. ${ }^{20}$ Mainly for this reason, the case attracted amicus briefs filed by academic institutions as well as major biotechnology and pharmaceutical companies. The Board of Patent Appeals and Interferences was unable to identify any 'substantial utility' or usefulness in the application for patentability of the ESTs. The Appeal Court agreed with this approach, stating that claimed inventions 'ought to have a specific and substantial utility' to satisfy the requirements of the US patent statute. The Court observed that the application comprised asserted uses based upon 'merely hypothetical possibilities' which had not yet been achieved in the real world. As the applicant did not identify the function for the underlying proteinencoding genes, the Court held that 'the claimed ESTs have not been researched and understood to the point of providing an immediate, well defined, real-world benefit to the public meriting the grant of a patent'. ${ }^{21}$

Although this decision imposed a higher patent standard, which might result in the invalidation of previously granted patents over research tools, this was not specifically addressed by the Court. However, it has been optimistically suggested that 'academic researchers as well as a considerable portion of the biotechnology and pharmaceutical industry will be satisfied by this judgment as it should reduce the number of parasite patents on gene sequences, in the United States'. ${ }^{22}$

A recent US case which has raised the very question of the patentability of genetic material is Association for Molecular Pathology $v$ USPTO in which a Judge of the United States District Court for the Southern District of New York delivered a summary judgment which invalidated patents related to the BRCA 1 and 2 breast and ovarian cancer susceptibility genes, which had been held by Myriad Genetics. ${ }^{23}$ The Judge held that the claims to DNA sequences in isolation were held to be insufficiently distinct from naturally occurring genes in the body and were thus products of nature rather than inventions. Significantly, he concluded that 'purification of a product of nature, without more, could not transform it into patentable subject matter. Rather, the purified product must possess "markedly different characteristics" in order to satisfy the requirements'. ${ }^{24}$ In his search for 'markedly different characteristics' the Judge focused on the function of a gene. He observed that DNA represents 'the physical embodiment of biological information, distinct in its essential characteristics from any other chemical found in nature and that DNA in an "isolated" form alters neither this fundamental quality as it exists in the body not the information it encodes' ${ }^{25}$

This decision was successfully appealed to the US Court of Appeals for the Federal Circuit (CAFC) in Washington, DC, which published its decision in August 2011. ${ }^{26}$ Circuit Judge Lourie, giving the opinion for the Court, considered that the district court had fallen into error in considering, not whether the isolated DNAs were markedly different from naturally occurring DNAs, but rather whether they had the same informational content as native DNA sequences. He pointed out that:

20. See Y Joly, 'Wind of Change: in re Fisher and the Evolution of the American Biotechnology Patent Law' (2006) 24 Law in Context 67, 75.

21. Ibid at para 36 .

22. Ibid at 80 .

23. Association For Molecular Pathology et al v United States Patent and Trademark Office et al, 09 Civ. 4515, March 29, 2010.

24. Ibid at 121 .

25. Ibid at 3-4.

26. The Association of Molecular Pathology \& Ors v The USPTO and Myriad Genetics Inc, _ F.3d_(CAFC, 2011). 
Adopting this approach, the district court disparaged the patent eligibility of isolated DNA molecules because their genetic function is to transmit information. We disagree, as it is the distinctive nature of DNA molecules as isolated compositions of matter that determines their patent eligibility rather than their physiological use or benefit. Uses of chemical substances may be relevant to the non-obviousness of these substances or to method claims embodying those uses, but the patent eligibility of an isolated DNA is not negated because it has similar informational properties to a different, more complex natural material that embodies it. ${ }^{27}$

Nevertheless, the CAFC considered that the district court was correct in holding that Myriad's claims directed to comparing and analysing gene sequences were not patentable, as these claims contained no transformative steps and covered only patent ineligible abstract steps. Circuit Judge Moore, concurring in part, noted that the isolation of a DNA sequence is more than separating out impurities, explaining that 'the isolated DNA is a distinct molecule with different physical characteristics than the naturally occurring polymer containing the corresponding sequence in nature' ${ }^{28}$ According to Circuit Judge Moore, the fact that human action had 'whittled the chromosomal DNA molecule down' to a shortened version of its natural self, 'defining the parts to be retained and discarded' rendered it 'entirely different' from the naturally occurring gene from which it was obtained. ${ }^{29}$ Circuit Judge Moore explained that whilst she might conclude that an isolated DNA sequence that includes most or all of a gene was not patentable subject matter if she was approaching the factual matrix from a blank canvas, this was not in fact the case as there was a 'substantial historical background' with the courts having been authorized by Congress to approach the issue of patentable subject matter expansively. Established practice had been to allow patents on isolated DNA sequences, such patents having being allowed by the USPTO for 'decades' according to the Judge. Accordingly, the Judge explained that she considered that "we must be particularly wary of expanding the judicial exception to patentable subject matter where both settled expectations and extensive property rights are involved. Combined with my belief that we should defer to Congress, these settled expectations tip the scale in favor of patentability. ${ }^{30}$ Both the plaintiffs and the defendants in this litigation have filed petitions for a rehearing of the case by the Circuit Court of Appeals. ${ }^{31}$

\section{DNA PATENTING AND AGRICULTURE}

The cultivation by farmers of GM crops has on occasion led to IP liability, where genetically modified (GM) seed is patented and the cultivation of that seed by the patentee is unauthorized. The cases are divided between those where farmers knowingly cultivate patented GM seed and those where the cultivation of patented seed is apparently inadvertent, for example, where crops are apparently pollinated by wind or insect-borne pollen.

An example of the first category of case is Monsanto Co v Scruggs, ${ }^{32}$ which

27. Ibid per Lourie $\mathrm{J}$ at 44 .

28. Ibid per Moore $\mathrm{J}$ at 11 .

29. Ibid per Moore J at 17.

30. Ibid per Moore $\mathrm{J}$ at 19.

31. See <http://www.genomicslawreport.com/index.php/tag/myriad-genetics/> accessed 8 December 2011.

32. 342 F. Supp 2d 584 (2004). 
concerned Monsanto's patented Roundup Ready ('RuR') glyphosate tolerant seeds. This was licensed to seed companies, who were obliged to sell the seed to growers who signed technology licence agreements acknowledging Monsanto's patent, and on condition that they could only be used by growers for a single commercial crop, that is, growers could not save seed produced from a harvested crop for replanting during the following growing season. Scruggs, who had not signed a technology licensing agreement, purchased a small quantity of RuR soybeans and cotton seeds, which were cultivated and from which he saved seed for further plantings. The Court decided that Monsanto's patent had been infringed by Scruggs, rejecting his defence that neither Monsanto's biotechnology nor the plants in their fields were covered by the patent and that the first sale of the seed embodying the invention exhausted the patent rights of Monsanto. The Court noted that Monsanto never made an unrestricted sale of its seed technology, as it licensed its technology to seed companies with a proviso: subsequent sales of seed containing its transgenic trait must be limited to growers who obtained a licence from Monsanto and for only a single growing season. ${ }^{33}$

A recent variant of these facts occurred in Monsanto Co $v$ Bowman ${ }^{34}$ where a farmer, Bowman, purchased commodity seeds from a local grain elevator which were not subject to a technology agreement. Following the application of glyphosate to the crops grown from these seeds, Bowman identified those which were glyphosate resistant and these were saved and re-planted in subsequent years, which enabled Bowman to use glyphosate-based herbicide. Monsanto filed a patent infringement claim against Bowman, and, in September 2009, the district court in Indiana granted summary judgment on patent infringement for Monsanto. Bowman appealed to the Court of Appeals for the Federal Circuit. Bowman argued that Monsanto's patent rights were exhausted under the first sale doctrine in relation to all second-generation Roundup Ready soybean seeds that were present in the grain elevators. He cited the 2008 Supreme Court case of Quanta Computer, Inc. v LG Electronics, Inc. ${ }^{35}$ In this case the Supreme Court held that sales of products that 'substantially embody' the disputed patents will also be considered sales that exhaust the patent right. Bowman argued that the Court should hold that subsequent generations of the seeds are 'substantial embodiments' of the first generation seeds, and thus the sales of these seeds would be exhausting sales. The Appeal Court held that even if Monsanto's patent rights in the commodity seeds were exhausted, such a conclusion would be of no consequence, because once a grower, like Bowman, planted the commodity seeds containing Monsanto's RuR technology and the next generation of seeds developed, the grower had created a newly infringing article. ${ }^{36}$ The Court observed that: 'The fact that a patented technology can replicate itself does not give a purchaser the right to use replicated copies of the technology. Applying the first sale doctrine to subsequent generations of self-replicating technology would eviscerate the rights of the patent holder.' 37

A case of apparently inadvertent infringement is illustrated by the Canadian litigation between Monsanto Canada, Inc and a farmer, Percy Schmeiser. Schmeiser grew canola commercially in Saskatchewan. He had never purchased Monsanto's patented RuR canola nor did he obtain a licence to plant it. Yet, in 1998, tests revealed that 95

33. Ibid at 591 .

34. (Fed Cir., 2011) at <http://wjlta.files.wordpress.com/2011/10/bowman.pdf> accessed 8 December 2011.

35. 553 US 617 (2008).

36. (Fed Cir., 2011), n 35 at 12.

37. Ibid. 
to 98 per cent of his 1000 acres of canola crop was made up of RuR plants. The origin of the plants is unclear. They may have been derived from RuR seed that blew onto or near Schmeiser's land. Monsanto brought an action for patent infringement. In finding patent infringement the trial judge ruled that the growth of the seed, reproducing the patented gene and cell, and sale of the harvested crop, constituted taking the essence of Monsanto's invention and using it without permission, and in so doing infringed the patent. ${ }^{38}$ By a majority of 5:4 the Federal Court of Appeal ruled that Schmeiser's saving and planting the seed, then harvesting and selling plants that contained the patented cells and genes appeared to the Court, on a common-sense view, to constitute 'utilization' of the patented material for production and advantage, within the meaning of s 42 the Canadian Patent Act. ${ }^{39}$ The argument that the infringing seed had merely grown as the result of wind pollination, or through the pollinating activities of birds and bees was rejected by the majority Judges as denying 'the realities of modern agriculture'. ${ }^{40}$ What was at stake in this case was sowing and cultivation, 'which necessarily involves deliberate and careful activity on the part of the farmer'. ${ }^{41}$ They noted that he had actively cultivated RuR canola as part of his business operations, thus in light of all of the relevant considerations, Schmeiser had used the patented genes and cells, and infringement was established.

\section{PATENTING OF STRESS-TOLERANT GENES}

The litigation referred to in the immediately preceding section illustrates some of the implications of DNA patenting in modern agriculture, both in its impact upon farmers and also its implications for the commodification of DNA. This section examines DNA patenting and climate-change agriculture. Somvanshi in a 2008 study identified 30 patents relating to drought tolerant genes. ${ }^{42}$ These included: (i) patents related to Proline biosynthesis ${ }^{43}$ (ii) patented dehydration responsive element binding factors (DREB) and C-repeat sequences binding factors (CBF); ${ }^{44}$ (iii) patents related to Protein Kinases ${ }^{45}$ (iv) various patents awarded for transcription factors involved in improving drought stress tolerance in plants; ${ }^{46}$ and (v) patents related to miscellaneous drought tolerance genes. ${ }^{47}$ A 2008 study by the ETC Group ${ }^{48}$ identified 55 patent 'families" 49 (a total of 532 patent documents) that were applied for and/or

38. Ibid, para 82, applying Pioneer Hi-Bred International Inc. v J.E.M. Ag Supply Inc. 53 USPQ (2d) 1440 (2000).

39. Monsanto Canada, Inc. v Schmeiser [2004] 1 S.C.R. 902, 2004 SCC 34.

40. Ibid at para 92 .

41. Ibid.

42. VS Somvanshi 'Patenting Drought Tolerance in Organisms' (2009) 3 Recent Patents on DNA \& Gene Sequences 16-25, Table $2<\mathrm{http} / / /$ www.benthamscience.com/dnag/samples/ dnag3-1/0003DNAG.pdf $>$ accessed 8 December 2011.

43. Eg US Patent 20087385106.

44. Eg US20087368630, US20077259297 and US20077253000.

45. Eg US20087345219.

46. US20087332651, WO2007028165A2, EP1676921, US20060272059, US7332651.

47. US20077262338.

48. The ETC Group is a non-governmental organization which describes itself as 'dedicated to the conservation and sustainable advancement of cultural and ecological diversity and human rights'. See <http://www.etcgroup.org/en/about> accessed 8 December 2011.

49. A patent family contains a set of related patent applications and/or issued patents that are 
granted to a number of biotechnology companies on so-called 'climate-ready' genes at patent offices around the world. ${ }^{50}$ Its 2010 update of this study 'examined patents containing claims concerned with abiotic stress tolerance (ie traits related to environmental stress, such as drought, salinity, heat, cold, chilling, freezing, nutrient levels, high light intensity, ozone and anaerobic stresses' ${ }^{51}$ It noted 'a dramatic upsurge in the number of patents published (both applications and issued patents) related to 'climate-ready' genetically engineered crops from June 302008 to June 30 2010, identifying 262 patent families and 1663 patent documents. ${ }^{52}$

\section{DEBATE ON THE ROLE OF CORPORATIONS IN THE PATENTING OF STRESS TOLERANT GENES}

The 2008 ETC report was subjected to a close analysis by Dr Carol Nottenburg, ${ }^{53}$ the Principal of a US Patent firm, and it is useful to examine the claims and counterclaims to identify the significant elements of the debate about the patenting of stress tolerant genes, as her comments are equally applicable to the 2010 ETC report. The ETC report stated that the so-called 'Gene Giants', exemplified by BASF, Bayer, DuPont, Monsanto and Syngenta 'are staking sweeping patent claims on genes related to environmental stresses' in patent offices around the world. Dr Nottenburg points out that the patenting of gene sequences is not permitted in a number of developing countries, including Andean countries, and an examination of the patents which are identified in the 2008 report have been sought in Argentina, Brazil and China, leaving more than 200 countries 'in which these patent applications will never be pertinent'.

Dr Nottenburg also pointed out that the number of patent families is the better indicator of the incidence of the patenting of stress-tolerant genes, than patent filings. This is certainly the case, as a number of filings are duplicated in different countries. The 2010 report identifies some 262 patent families which is a considerable advance on the 55 identified in the 2008 report. However, it should be noted that even a small number of patent families can have a considerable political impact. For example, if the number of biopiracy incidents was totalled, they would probably not exceed around 20 causes célèbres.

The 2008 report is critical of over-broad patent claims, but Dr Nottenburg considers this to be a matter dictated by the 'eye of the beholder', and in one case involved an error in the published patent document. She concludes that 'visions of gene-grabbing

published in more than one country or patent office (including national and regional patent jurisdictions). Issued patents and/or applications that belong to the same family have the same inventor and they refer to the same 'invention'.

50. ETC Group, 'Patenting the "Climate Genes" ... and Capturing the Climate Agenda' Communiqué 99 May/June $2008<$ http://www.etcgroup.org/upload/publication/687/03/ etcgroupclimategenesfinal05_08.pdf>.

51. ETC Group, 'Gene Giants Stockpile Patents on "Climate-ready" Crops in Bid to become "Biomassters": Patent Grab Threatens Biodiversity, Food Sovereignty' Issue no 106, October $2010<\mathrm{http}: / /$ www.etcgroup.org/upload/publication/pdf_file/FINAL_climate-readyComm_ 106_2010.pdf $>$.

52. Ibid, Appendix A.

53. C Nottenburg, 'Patenting the "Climate Genes ... and Capturing the Climate Agenda": A Communiqué by the ETC Group' Harvest Choice Commentary, 7 August 2009 $<$ http://www.harvestchoice.org/files/Nottenburg\%202008\%20HarvestChoice\%20Patenting\%20the\%20Climate\%20Genes 2S.pdf>. 
and holding farmers hostage are unwarranted'. A particular problem had been that patent applicants had been allowed to make bulk claims in relation to genetic material of which the use had not yet been identified. However, the 2010 report concedes that in 2001 the USPTO put a brake on 'bulk claims' by issuing new guidelines requiring that claimed inventions must have 'well-established' utility and that in 2007 the USPTO limited bulk claims by notifying its patent examiners that they had the option of restricting claims to only a single nucleotide sequence in each patent application. ${ }^{54}$

The 2010 report of the ETC contrasts the ownership of 9 per cent patent families by public sector institutions ( 9 per cent of the total) with the private sector which holds 91 per cent of the total. As is the case with biotechnological patenting generally, proprietary biotechnologies are concentrated in the same few corporations. ${ }^{55}$ The 2010 report points out that 'just three companies - DuPont, BASF, Monsanto account for two-thirds (173 or 66\%) of the total'. This level of market concentration gives cause for concern to those who espouse the positive role of competition.

In addition to the possible adverse impacts this market concentration might have upon the vigour of competition, the market dominance of these private corporations also has an important influence upon the sort of biotechnological research which is undertaken. For example, to what extent will the dominance of private corporations in biomedical and agricultural research direct that research towards Northern concerns away from Southern food priorities. ${ }^{56}$ It has been estimated that only 1 per cent of the research and development budgets of multinational corporations is spent on crops likely to be useful in the developing world. ${ }^{57}$ Almost entirely neglected by these corporations are the five most important crops of the poorest, arid countries sorghum, millet, pigeon pea, chickpea and groundnut. ${ }^{58}$

\section{COMPETITION IMPLICATIONS}

The UN's Special Rapporteur on the Right to Food, in his 2008 Report warned that:

[E]xtending patents to plant varieties ... would accelerate the 'verticalization' of the food production chain, as agricultural producers would become dependent on the prices set by companies for the seeds on which they have patents and would be denied the traditional right to sell and exchange seeds among themselves, as well as to save part of their crops in order to retain seeds for the next planting season - either as a consequence of the protection of patents or by the use of 'technology use agreements' by companies selling seeds. ${ }^{59}$

54. Referring to 1316 O.G.13, 27 March 2007.

55. Eg see W Lesser, 'Intellectual Property Rights and Concentration in Agricultural Biotechnology' (1998) 1(2) AgBioForum 56.

56. J Alston, G Pardey and J Rosenboom, 'Financing Agricultural Research: International Investment Patterns and Policy Perspectives' (1998) 26 World Development 1045.

57. PL Pingali and G Traxler, 'Changing Focus of Agricultural Research: Will the Poor Benefit from Biotechnology and Privatization Trends?' (2002) Food Policy 27.

58. Human Rights Council, Report of the Special Rapporteur on the Right to Food, Jean Ziegler, A/HRC/7/5, 10 January 2008, para 44.

59. Report of the Special Rapporteur on the Right to Food (2008), United Nations, General Assembly A/63/278* <http://www2.ohchr.org/english/issues/food/docs/A.63.278_en.pdf>, p. 13. 
His 2009 Report added that the development of IPRs on agriculture would lead to transfers of resources from technology users to technology producers, both within States and between States and that the oligopolistic structure of the input providers' market could result in poor farmers being deprived of access to productive resources essential for their livelihoods, leading to increases in food prices. ${ }^{60}$

\section{CONCLUSION}

The application of IPRs to genetic resources has become a pronounced feature of agricultural innovation in the past decade. The Food and Agriculture Organization of the United Nations (FAO) Panel of Eminent Experts on Ethics in Food and Agriculture has observed that 'while most innovation for food and agriculture does not depend on IPRs, the acquisition and exercise of IPRs in this field raise a variety of ethical concerns'. ${ }^{61}$ These include the fact that 'IPRs protection may just mean the lack of access to innovations for the poor' and the concerns raised by the 'patenting of merely isolated genes, the basic building blocks of life', which 'are not invented, but are part of nature' ${ }^{62}$ More practically, the ability of individuals and corporations to obtain proprietary rights over agricultural innovations has important implications for food security, ${ }^{63}$ particularly as the expense and general transactional costs have tended to concentrate such IPRs in a few hands. The patenting in relation to genetic material which might be useful in permitting organisms to resist the stresses of climate change mirrors the high market concentration levels which have already been observed in the seed industry and the control of patent thickets by a small number of companies.

The practical effects of the application of IPRs to genetic resources is reflected in the actions which have been brought for infringements of IPRs. To date, these actions have mainly been brought against farmers who have cultivated patented GM crops without the permission of the relevant rights holder, as well as actions against importers of products containing patented GM ingredients. Potential IPR liability also lies against governments, research institutes (international and national) and seed breeders who supply or utilize the proprietary technologies which are indispensable for the development of climate resistant crops.

60. General Assembly, The Right to Food. Seed Policies and the Right to Food: Enhancing Agrobiodiversity and Encouraging Innovation A/64/170, 23 July 2009, paras 26-27 $<$ http://www.keinpatent.de/uploads/media/seed_policies.pdf $>$.

61. Panel of Eminent Experts on Ethics in Food and Agriculture, 3rd Report (2005), available at <http://www.fao.org/docrep/010/a0697e/a0697e00.htm>.

62. Ibid.

63. See M Blakeney, Intellectual Property Rights and Food Security (Wallingford, Cab International 2009). 